\title{
Rural retailing: a sector in decline?
}

\author{
Andrew Paddison* and Eric Calderwood** \\ Institute for Retail Studies* \\ Department of Marketing \\ University of Stirling \\ Stirling FK9 4LA \\ Tel: 01786467397 \\ Fax: 01786464745 \\ e-mail: a.r.paddison@stir.ac.uk
Eric Calderwood Associates**
38 New Endrick Road \\ Killearn G63 9QT \\ Tel: 01360550747 \\ e-mail: ericcalderwood@ukgateway.net
}

* corresponding author 


\title{
Rural retailing: a sector in decline?
}

\begin{abstract}
Purpose - The paper reviews dynamic forms of rural retailing, by location, that have innovated through a mixture of actions leading to growth, adaptation, diversification and differentiation.

Design/methodology/approach - Reviews relevant academic literature and draws upon contemporary policy-related material that details recent innovation within the sector. A rural retail typology by location is presented: retailing within market towns, village shops and stand-alone retailing forms (farm shops and speciality rural retail outlets).

Findings - Since the nature together with form of what characterises dynamic and innovative rural retailing differs by location, the typology is based on the above schema. First, market towns have used growth and differentiation opportunities as strategic foci. Secondly, innovative village shops have applied strategies that seek to counter their structural weaknesses, harness the community and yield new revenue streams. Thirdly, the manner in which stand-alone retailing forms, such as farm shops together with speciality rural retail outlets, have grown and developed is reviewed.
\end{abstract}

Practical implications - Reviewing dynamic forms of rural retailing allows for a greater understanding of the operational needs for success. Home (2002) cited a lack of relevant research. Examples are illustrated in Tables I and II.

Originality/value - Stereotyping rural retailing is erroneous since marginalised enterprises are juxtaposed against more innovative forms. Contrary to perceptions of rural decline, the sector is multi-faceted with prospering sub-sectors. The paper focuses on these more dynamic and innovative forms of rural retailing. Much of the previous focus in this sector has been on negative issues and decline (Vias, 2004). A synthesis of the key contributory phenomena is presented (Table III).

Paper type Conceptual paper

Keywords Rural retailing, Growth, Adaptation, Diversification, Differentiation. 


\section{Rural retailing: a sector in decline?}

\section{Introduction}

Rural retailers are disadvantaged due to geographic isolation, unfavourable cost structures and restricted population catchments (Figure I). Consequently, trading conditions may be inefficient and pressured. Since rural retailers can be social hubs fostering the community, the sector's contraction (NEF, 2003) has impacted negatively. Diversity and heterogeneity characterises rural areas. Whilst associated with economic decline, low incomes and poor service provision, any analysis should avoid generalisations (Hodge and Monk, 2004). Notwithstanding geographic isolation, there are varying levels of remoteness with less remote districts experiencing leakage to larger retail centres. Secondly, certain retail forms, such as farm shops, have grown and differentiated with innovation being juxtaposed against more marginal sub-sectors. Stereotyping the sector is erroneous.

Take in Figure I

The aim of the paper is to review dynamic forms of rural retailing, by location, that have innovated through a mixture of actions leading to growth, adaptation, diversification and differentiation. Contrary to perceptions of continued and perpetual decline, the paper highlights the sector's variety by location: retailing within market towns, village shops and stand-alone retailing forms (farm shops and speciality rural retail outlets). By reviewing more dynamic forms, the operational needs for success can be understood with Home (2002) citing a lack of relevant research. Before outlining the typology, the complexities in defining a 'typical' rural retailer are highlighted. Thereafter, the factors disadvantaging the sector, which 
lead to a loss in custom, are discussed. Concomitantly, their community role together with the negative repercussions if this consumer utility is lost is detailed. Finally, contemporary developments centring on the quality and 'localness' of rural products are reviewed.

\section{Rural retailing}

\section{Defining 'rural' and 'rural retailing'}

Amongst the multitude of rural definitions, there are common variables: the number of settlements below a certain threshold, population density and finally, 'non-urban' areas (Shucksmith, 1990). Rural areas are those of a settlement size of less that ten thousand, which incorporates villages, hamlets and isolated dwellings (Countryside Agency, 2004d). Although this defines the parameters, differing levels of remoteness and peripherality from large population concentrations are not accounted for. However, the Scottish Executive (2002) has distinguished between accessible rural areas - defined as within 30 minutes drive of a town above 10,000 - as opposed to remote rural areas. This only begins to capture variations.

In applying rural definitions to retailing, the significance of population concentration together with thresholds depends on retail type with non-food requiring a larger catchment than grocery stores. Typically, independent ownership together with a discrete and constrained catchment allied to a degree of 'remoteness' has characterised the sector. However, rural retailing exists outwith these parameters. Symbol groups, such as Spar, exist in the food sector and market towns contain multiples. In the market town of Callander (Stirlingshire), the Tesco Express format is indicative of multiple stores locating further down the settlement hierarchy. Consequently, rural retailing encompasses independent outlets together with national chains. 
Grampian Regional Council (1989) defined a 'typical' rural retailer. There are identifiable features: independent ownership as a sole trader, relatively distinct and discrete catchment, fairly short period of current ownership, dependence on part-time staff, long opening hours, low usage of training but potential willingness to partake in the future, fairly wide range of general grocery items, mixture of food and non-food functions, customer patronage orientated towards additional shopping, reliance on local wholesalers, ageing shop infrastructure and a relatively static or only marginally improving shop environment.

This definition has caveats. First, the levels of competition are a function of the proportion of outlets relative to population density. However, this is premised upon customers residing within a certain radius. Crucially, it does not allow for inshopping; a working definition being trade from a catchment residing beyond a normal travelling distance. Secondly, rural retailing consists of food and non-food outlets, whereas the council's definition was orientated towards grocery. Thirdly, discretionary shopping as distinct from grocery spend is not incorporated. In effect, it does not account for leisure instead of only functional shopping.

Fourthly, the differing scale of rural retailing is not accounted for. Finally, an emphasis upon relatively stressed trading does not capture development and growth; in contrast, it is predicated upon relatively undynamic trading conditions. Crucially, rural retail outlets are not specified by turnover or employee numbers. Smith and Sparks (1997) defined a small shop as an outlet with an annual sales figure of less than $£ 175,000$ and fewer than 10 full-time or equivalent employees. However, rural retailers may have developed beyond these parameters. 


\section{Scale of rural retailing}

Dawson (2000) commented on the inadequacy and gaps in retail data, whilst Smith and Sparks (2001) highlighted inconsistencies that make data interpretation problematic. Hill (2003) expressed dissatisfaction with the quality of rural statistics and data. Notwithstanding these limitations in available data, rural services across the UK have declined and contracted with net closures being the on-going pattern for village shops (Countryside Agency, 2005). Parallels can be drawn with the US where an increasing number of rural enterprises fail to develop or continue trading (Miller, 2001), whilst Home (2002) indicated that the number of rural stores in Finland in 2001 was only a third compared to 1985.

Historically, there has been an identifiable decline of rural shops. Shaw (1982) noted that almost half of all Dorset villages lacked any retail form; these trends have continued with the DETR (2000) noting that 4000 food shops closed from 1991 to 1997. Approximately threequarters of English rural settlements lack both a general store and village shop, although a comparable proportion of rural households reside within four kilometres of a supermarket (Countryside Agency, 2001b). Bank branch numbers have declined; in rural Aberdeenshire, for instance, the number has fallen by 42\% since 1981 (Aberdeenshire Council, 2004) with shop numbers declining by $22 \%$ during the same period.

Fewer than 12,000 rural shops are thought to be still functioning with an annual contraction of approximately 300 units (NEF, 2002). Recent commentary has focused on the oftmentioned figure of seven out of ten villages and towns lacking a shop. However, the veracity of this has been critiqued with calculations indicating that $54.6 \%$ of all rural parishes lack a general store or village shop (DETE, 2005). Crucially, though, this excludes farm shops and mobile outlets. Recent research (Rural Shops Alliance, 2005) indicated that were 
72,225 rural retail businesses in England. Basically, determining the exact numbers and types of rural shops is fraught with definitional complexity and inconsistency.

Despite these limitations, though, these figures need to be situated alongside changing demographics. Growth has been greater than in urban areas and around 14 million people (28.5\% of the population) reside in England's rural districts. Paradoxically, retail service decline has been accompanied by a growth in overall population, albeit with regional variations.

\section{Trading conditions and customer trends}

Bates (1976), Jones and Oliphant (1976), Dawson and Kirby (1979) and Dawson (1983) highlighted the generic problems of small shops. These have been attributed, first, to inadequacies in the trading environment such as economic and social change, competition from multiple retailers and locational difficulties. Secondly, there were a series of identified inadequacies in the retail form: operating costs, investment capital availability and supply problems. Finally, a lack of management expertise was identified as a key constraint. In addition, the Rural Shops Alliance (2005) discussed the costs of regulatory compliance that burdens and inhibits rural retailers.

Although these are relevant to a rural context, there are distinctive aspects. Higher stockholding and transport costs results in unfavourable cost structures. Achieving operational efficiency can be problematic. Logistically, the relative remoteness coupled with a small population results in small and correspondingly expensive delivery sizes. Achieving cost efficiencies and economies of scale is more difficult due to these delivery restrictions. However, this is premised upon suppliers being available and willing to deliver. 
Small and geographically constrained customer bases provide a limited scope to attract new segments. Leakage, in terms of expenditure occurring outwith the locale, compounds this. Accompanying this, there are longstanding traditions of rural consumers compensating for their remoteness by using mail order retailing (Scottish Executive, 2000). Broadband penetration was predicted to rise to $80 \%$ by 2005 with community networks being a suitable conduit through which to achieve this (Countryside Agency, 2003a). Since a cited benefit was 'more efficient shopping', the increasing prevalence of rural broadband coverage - albeit lower in comparison to many conurbations (Countryside Agency, 2004b) - will facilitate and intensify non-store retailing. As a comparison, rural Americans use online shopping more than any other segment (Hitwise, 2004).

Outshopping to larger retail destinations results in the loss of local custom (Lumpkin et al., 1986; Marjanen, 2000). Broadbridge and Calderwood (2002) defined outshoppers as consumers whose primary shopping occurs outwith the immediate area, whilst LaForge et al. (1984) defined it as patronage occurring outside of the local community. Whether through choice, habit or necessity, consumers access retail services in larger towns. Retail contraction has intensified these trends since the focus of shopping will be where multiple services are clustered.

Outshopping has several effects. First, there are multiplier effects if local services are either wholly or partially dependent on a retailer's customers. Interdependencies between retailers existing in a retail ecosystem are crucial (Simms, 2003). Secondly, many shopping trips entail multiple purchases and a shrinking number of outlets reduces a location's utility, thus encouraging continued outshopping (Home, 1993). The prevalence of outshopping has been attributed to dissatisfaction with local retail provision (Riecken and Yavas, 1988) and is 
closely associated with higher income segments (Thompson, 1971). Where the nearest town is relatively proximate the impact may be more pronounced and remoter areas are, in contrast, less vulnerable. Home (1993) suggested that a more peripheral location reduced the propensity of rural store closure and, consequently, closer proximity to an outshopping destination increased the likelihood of failure.

‘Top-up’ supplementary shopping exists simultaneously with outshopping. Local shops, as opposed to outshopping destinations, are used in different contexts. Larger retail centres tend to account for the majority of primary shopping visits (Harman, 1978); in contrast, rural shops are disadvantaged since a relatively small proportion use them as their primary destination (Scottish Executive, 2000). Multiple chains, such as Tesco Express, have expanded in market towns to target supplementary and primary shopping segments simultaneously.

\section{Economic and social significance of rural retailing}

There are repercussions if the rural retail stock declines. First, an impoverished range of outlets can result in consumers shopping elsewhere. Since an agglomeration of retail outlets has economic benefits for the area, the effects are compounded. Secondly, reduced custom for local suppliers results in a less competitive trading environment if remaining outlets cannot be serviced cost effectively. Thirdly, there will be a loss of local jobs - directly through closures and indirectly through the reduced need for associated services - and finally, consumers have less choice. Since disadvantaged groups lack the mobility to shop elsewhere, sparser retail facilities has a negative impact. Concern over access to local facilities has been a recurrent theme of policy-making (Harman, 1978). 
In short, a healthy rural retail sector can help to stem depopulation and stimulate growth. An area's prosperity and the state of rural retailing are interdependent and intertwined. Rural retailing is crucial for the owner/manager's livelihood, together with any additional employees, with evidence indicating that village shops can open for 110 hours per week (Smith and Sparks, 1997). The need for part-time employees helps to sustain local employment.

Socially, rural retailing acts as a community hub (Kirby, 1982a), and provides a channel for events (Sullivan and Savitt, 1997) and information dissemination. Losing this provision has a detrimental impact on a village's social life and identity (Kirby, 1982b); to minimise this, the high level of community spirit existing within rural households - identified by Williams (2003) - can be harnessed. Closure can lead to a loss in distinctiveness allied to increasing homogeneity with Home (2002) identifying social and communicative roles as being indelibly linked with rural stores. Local residents rated primary schools, village shops, post offices, surgeries and petrol stations as key services (Scottish Office, 1995) with the first two as most important. Smith and Sparks (1997) highlighted the indispensable role of a proximate convenience store with Mackay and Laing (1982) according greater primacy to this facility than other institutions: church, pub and police station.

Evidence on customer satisfaction with rural shopping facilities suggests that positive sentiments do not automatically translate into patronage. MacNee (1996) highlighted high levels of satisfaction with rural shops, although the Scottish Executive (2000) suggested that local shops had less favourable ratings compared to retail outlets that comprised a 'main' shopping visit. Consequently, the product offering needs to be tailored, so that purchasing patterns can be reconciled with attitudes. Ultimately, the nostalgic view of the village shop is 
not sustainable. Whilst they may be cherished, there may be insufficient patronage to warrant a continued existence (The Grocer, 1996).

\section{'Localness' and distinctiveness in rural areas}

Notwithstanding these trends, there are positive external drivers. By capitalising on the distinctive and valued characteristics of rurality connected with amenity and identity, a series of viable business opportunities have emerged (Anderson and McAuley, 1999). Consumer interest has focused on using the quality and 'localness' attributes of rural products as marketing assets (Morris and Buller, 2003), while Burnett and Danson (2004) linked this form of diversification with distinct and specific representations of local culture. Weatherell et al. (2003) noted greater interest in locally derived food produce. In targeting segments with the necessary inclination, mobility and discretionary spend, there has been a corresponding growth in retail enterprises.

Depending on the quality and premium placed upon products and services, speciality retailers in rural areas have accessed both national and international markets. As an example, the contact details within the House of Bruar (Perthshire) website refers implicitly to their international audience, whilst the Scotts of Stow (Gloucestershire) website explicitly mentions their international customer base. Significantly, these segments seek products that warrant a price premium, trade on their local identity (Bessiere, 1998) and are bought by consumers seeking a destination retail environment in their leisure time. Consequently, they complement rather than supplant existing provision by attracting new inshopping customers. Scenario planning has identified that demand by non-rural residents, in the form of visitors, will be an important external driver (DEFRA, 2005b). Non-store retailing can target this 
segment to maintain the momentum of purchasing and communication. Many products can be retailed through the web, thus extending their diffusion.

The foregoing discussion has highlighted the external drivers affecting this sector. Growth opportunities exist alongside pressured and adverse trading conditions. Existing and emergent rural retailers have positive qualities and roles. Rural retailing perceptions revolve around images of decline; essentially, there is a caricature of the marginal village shop. In practice,

rural retailing is multi-faceted with prospering sub-sectors such as farm shops. Vias (2004) noted that the focus in this sector has been on negative issues and decline. Relatively little attention has been paid to the issue of rural retailing in the last decade (Byrom et al., 2001a), although studies have examined rural food retailing in Scotland (Byrom et al., 2001b). Smith and Sparks $(2000,2001)$ discussed the sector within the wider context of small independent retailers. Therefore, there is a need to review rural retailers by location with a focus upon the more dynamic examples. The remainder of the paper will review these existing and emergent rural retailing forms.

\section{Rural retail typology by location}

Since the nature together with form of what characterises dynamic and innovative rural retailing differs by location, the typology is based on the following schema: retailing within market towns, village shops and finally, stand-alone retailing forms whether farm shops or speciality rural retail outlets. Since the strategic foci of growth, adaptation, diversification and differentiation are coalescent rather than discrete, there was a rationale for the typology to be organised on the basis of location. By doing so, there is recognition that these strategies can occur simultaneously, whereas Jussila et al. (1992) viewed expansion, adaptation and diversification separately. Contrasts can also be established with Byrom et al. (2003) in their 
distinction between strategies that seek to merely ensure business continuance as opposed to those that may result in expansion. Rather, the typology focuses upon the more innovative and enterprising forms of rural retailing. In the conclusion, a synthesis of the key contributory phenomena that exemplify these forms of rural retailing is presented.

\section{Market towns}

Market towns range from 2,000 inhabitants to 30,000 (CPRE, 2004b), although only smaller examples are within the 10,000 threshold (DEFRA, 2004b). Many of these towns have played a longstanding role in servicing their immediate community and hinterland (Powe and Shaw, 2004) with their retail provision (Phillips and Swaffin-Smith, 2004). As centres for economic exchange and social interaction, they provide a range of retail, leisure, cultural, professional and public sector services. In contrast to popular perceptions of rural stagnation or decline, market towns may service a prosperous hinterland. Since these segments may possess a high disposable income, the retail mix can reflect this discretionary spending.

Identifying useful and marketable assets allows for effective differentiation (Table I). Characteristics such as the architectural heritage, local history, the physical setting, an identifiable character and community spirit are valued attributes for these towns to capitalise upon (Countryside Agency, 2004a). Through these qualities, there may be scope to market themselves as distinctive places to live in or visit. By distinguishing between different segments - local residents, day visitors and tourists - the relevance of different retail and associated functions can be identified.

Take in Table I 
The majority of smaller market towns are orientated towards convenience shopping, locally based comparison retailing and some specialist functions. Outshoppers from outlying rural districts may visit the town. In turn, though, these market towns lose outshoppers to larger towns; consequently, they fill an intermediate role within the retail hierarchy. By cementing their current role together with achieving growth through additional patronage, the leakage to larger towns can be partially stemmed.

Compared to larger towns, the amalgam of multiple and independent retailing allows a market town to appeal to consumers seeking greater retail diversity. Where multiples predominate, the increasing uniformity, as documented in a NEF (2005) survey, has led to indistinguishable and identikit high streets. In contrast, the distinctiveness of the independent retail stock can allow market towns to present themselves favourably (Action for Market Towns, 2003). If these towns can capitalise upon powerful local associations and identity, an element of non-food comparison retailing can exist if its scale is proportionate to the local catchment. Compared to previous characterisations of outshopping being a negative phenomenon, a certain proportion of this segment can be retained locally.

Whilst primary food together with an element of non-food retailing can target the local population, there are additional segments of day visitors and tourists. Many retail outlets target these segments simultaneously, although the former may visit on a greater frequency. Market towns have specialised in distinct product categories; Tetbury (Gloucestershire) has a sizable cluster of antique shops, whilst Hay on Wye (Herefordshire) focuses upon books. Through locational clustering of similar retailers, a town may differentiate itself on the basis of this competitive edge and promotional angle. In addition to permanent retailing, opportunities exist for periodic farmers markets and flea markets. Alternative retail forms can 
engender and foster curiosity amongst incoming customers as well as local residents. Increasingly, the contribution of markets to a market town's product mix is being recognised (Countryside Agency, 2001a; Action for Market Towns, 2002). Farmer market numbers have increased to around 450 with around 4500 separate farmers markets occurring annually (NFU, 2002). Youngs (2003) noted that the majority of markets in North-West England were classified as prospering.

Proximity and accessibility to larger population concentrations allow market towns to benefit from inshopping from day visitors. Simultaneously, the growth of short-breaks - as a proportion of the tourist market - has accompanied this greater interest in localness. Segment growth in visitors (PIU, 1999) and short break tourists (DETR, 2000) was predicted. In sum, these phenomena partially refute the argument that retail spending is flowing in a unidirectional manner out of rural districts. An attractive market town with a relevant retail offering can lead to a partial reversal of this process.

\section{Village shops}

Developments within the village shop sector help to counter perceptions of malaise and terminal decline. Rather than village shopkeepers acting passively in the face of adverse external forces, there have been proactive responses (Table II). There are three influencing factors: first, the desire to tackle structural weaknesses; secondly, a need to yield new revenue streams and thirdly, a recognition that the community's positive qualities can be harnessed. In practice, these strategies merge rather than being discrete.

Take in Table II here 


\section{Mixed-merchandising}

By offering various functions at one location, the growth of mixed-merchandising fuses retailing with other services to create a multi-purpose outlet (Jones and Smith, 2000; Countryside Agency, 2003b). Amalgamating different functions, such as pubs with post offices (Countryside Agency, 2001c; Pratten and Lovatt, 2002), helps to ensure a continued presence by offering greater consumer utility (DEFRA, 2004a). Since the number of post offices has fallen (White et al., 1997), it may help to slow or stem this decline. Internal organisational synergies, together with cost advantages, can be yielded. Crucially, these organisational benefits can be instrumental in ensuring business continuation. Function enlargement should be compatible with prevailing patterns of retail provision. Enlarging the operational scope where a static or declining population resides may result in cannibalisation amongst local outlets and, ultimately, a decreasing retail choice (Jussila et al., 1992). If properly implemented, though, new revenue streams can be accessed. Through achieving greater returns, the pressure on margins is alleviated.

\section{Technology}

Service adaptation and diversification can also be achieved by exploiting technology. By offering banking services, there is an increased likelihood of additional traffic and revenue. For consumers this provision helps to ameliorate for their relative geographic isolation. In sum, it is a suitable mechanism that ensures consumer availability within realistic cost parameters. Scope also exists to incorporate information points into village shops (LGA, 2000). Routing web access and library borrowing through these channels can ameliorate a customer's relative peripherality and increase their incentive for patronage. Overall, mixedmerchandising and service amalgamation allows for continued provision or, alternatively, previously unavailable services to co-exist. 


\section{Community function}

Ultimately, village shops can position themselves as community resources through the fusing of product and service functions. Adept strategies have increased the likelihood of positive sentiments translating into usage. Initiating community events that are explicitly associated with the store helps to strengthen ties. Although this bond may pre-date the events, these forums can re-energise the community. As well as being a platform for local events, there are mechanisms to engage the community at the operational level.

Village shops can incorporate social facilities. By acting as a focal point that provides an invaluable service, the community role can be reinforced. In doing so, retailers can create and capitalise on favourable comparisons with retail environments that are perceived to be depersonalised. By playing a pivotal role in community life and by embedding themselves into the local social milieu, this can assist in the functioning of the business (Miller et al., 2003). Co-operative mechanisms, such as village shop associations, have been used to increase the community's commitment and willingness to invest. To facilitate this, a number of community enterprises have received funding; for example, a grant was awarded to the Timsgarry shop and petrol station (Western Isles). However, public subsidies have to be accompanied with sustained levels of community support for enterprises to continue; for example, the Airth Community Co-Op (Falkirk) closed after the subsidy finished. From a shopkeeper's perspective, a corollary of community involvement should be to lessen the incurred risk and so maximise the likelihood of the business continuing. Through marshalling the community and giving them a direct stake in a shop's functioning, a greater number of residents may choose to use it as their primary shopping destination instead of outshopping. 


\section{Product mix}

Strategies operating within current product parameters can be deployed. Product lines can be adapted so as to accord with local preferences. Additionally, the constraints of a restricted catchment can be partially compensated through offering delivery to outlying areas. Alternatively, product lines can be retrenched and condensed to correspond with the reduced demand. Through offering a wide range of product categories, albeit with a shallower depth in each category, internal cost structures can be reconciled with reduced demand. Product duplication and stock-out problems are reduced, whilst a wide range of product categories may offer an incentive for outshopping segments to return.

More professional merchandising techniques ameliorate for the structural weaknesses associated with balancing unfavourable cost structures, as opposed to ensuring product availability. Initiatives in co-operation with major suppliers in convenience categories have focused upon optimising space utilisation. Reallocation has resulted in different apportionment within product categories. In particular, the scenario where product category depth was out of proportion to demand, thus resulting in out-of-stock situations, has been recognised. Consequently, product category width has been reconciled with the depth of category choice; in achieving this, a parallel can be drawn with Kirby (1982b). Sufficient choice can be ensured and retailer margins increased.

Village stores have enhanced their merchandising strategies by collaborating with national chains. For example, the Sainsbury's Assisting Village Enterprise Scheme (SAVE) allows a village store to stock own-brand lines (BITC, 2003). Initiatives exist between Tesco and village shops in South Norfolk (DEFRA, 2005a), whilst the Eday Community Enterprises's shop (Orkney) has supply chain arrangements - as do other Scottish community co-ops - 
with the Co-operative group (Meteyard, 2005). Village stores are able to take advantage of an established brand name's promotional visibility and, in comparison to wholesalers, participants have greater discretion as to which stock lines to focus upon (PR Newswire Europe, 2003) and are able to purchase smaller quantities (North Devon Journal, 2003).

\section{Local produce}

Accompanying the trend of space allocation to national own-brands, increased visibility has been given to local produce that uses uniqueness as a marketing tool. Since these products are linked explicitly to a locale, they can engender pride and a sense of belonging for local shoppers. Concomitantly, the local associations can be evoked through the packaging used and, consequently, they have an integral role in raising the area's identity amongst visitors. Seasonal fluctuations in visitor numbers can warrant a degree of product adaptation with local produce focusing on this discretionary spend. Local produce can complement standardised product lines by generating greater consumer interest. Since expansion of the local food sector was predicted (CPRE, 2002b) with local consumers increasingly seeking these items in their primary shopping visits (CPRE, 2004a), there is a rationale for this focus.

Local sourcing can help retailers circumvent pre-existing supply chains through the greater proximity to producers. Cost advantages resulting from supplier flexibility and proximity may accrue to retailers, thus ameliorating for some of the structural weaknesses. Retailers access these products directly from producers or, alternatively, through an intermediary network. Within a tight geographic radius, the routing of products - through either of these channels - is indicative of local interdependencies (CPRE, 2002a). 


\section{Strategic rationale and suitability}

Despite the rationale for mixed-merchandising, technology improvements, community initiatives and local produce, these developments need to be gauged with reference to the relative proximity of larger retail centres. Ultimately, a successful village shop should reduce the prevalence of outshopping by increasing market share. At the same juncture, the sector needs to recognise its limitations for consumers who are able to purchase in larger retail formats. Therefore, they need to identify their useful and distinctive assets rather than simply replicating larger competitors. In capturing local shoppers, it has been demonstrated that the majority of regular customers in shops that sell local produce reside locally (Countryside Agency, 2004c). Consequently, there is scope for differentiation and for reducing previously cited perceptions that a rural household's retail provision compares unfavourably to their urban counterparts (Hildebrandt, 1987).

In addition to targeting local custom, the sector can increase its inshopping appeal and, consequently, reduce its dependence on local trade (RDC, 1994). This demonstrates that proximity to larger population concentrations yields opportunities. In rural areas where outshopping is less prevalent, the objective should be to ensure the continuance of the outlet. In achieving this, non-economic roles need to be stressed. Ensuring survival and development requires that consumer utility, in terms of a greater product and service offering, be maximised. In replicating successful innovation within this format, there are preconditions. First, the significance of outshopping together with its local market share needs to be recognised and secondly, an element of community goodwill that materialises itself in patronage is needed. 
Ultimately, there is a dichotomy emerging within the village shop sector. More innovative enterprises have shown a willingness to adapt and be responsive to changing conditions (RDC, 1993). At the other end of the spectrum, there are outlets that have insufficient management skills or the will to change (Countryside Agency, 2002).

\section{Stand-alone retailing forms (farm shops and speciality rural retail outlets)}

FARMA (2005) estimated that approximately 3500 farm shops exist in the UK with FARMA (2004) identifying that a third of households visit these retail forms annually. Further scope for growth has been predicted (IGD, 2005). In contrast to farmers markets, farm shops sell local produce directly and have greater permanence. By promoting the region's distinctive produce, a locality's identity can be reinforced through the generated images. Collective marketing initiatives increase the awareness of branded regional produce. Crucially, joint approaches afford greater leverage and presence to these retailers than otherwise possible. Increased consumer interest and receptivity in produce where there is greater immediacy with producers has paralleled farm shop growth. In turn, producers have responded proactively by educating segments that seek high quality produce. Collaborative marketing initiatives, consequently, have channelled the momentum created through this heightened consumer concern that centres on produce origin and providence.

Interdependencies between this retail form and other components of the rural economy exist. Through encouraging local enterprises - such as catering and accommodation providers - to stock produce, a number of objectives can be achieved. First, it circulates revenue and custom locally. Secondly, it lessens dependence upon the fluctuating segment of seasonal inshoppers. Thirdly, the visibility of local produce can be enhanced if its origin is obvious. Ultimately, local supply chains and marketing networks benefit. 
By selling directly, the producer retains a larger proportion (LaTrobe, 2001). Additional cost advantages accrue through the more minimal packaging and reduced transport costs obtainable through shorter food miles. Greater interaction and feedback with purchasers can facilitate the future refinement of produce. Overall, diversification that focuses on these segments yields additional revenue, does not cannibalise existing business and lessens dependence upon pre-existing custom. Compared to other forms of farm diversification, the proportion of total income contributed by retail activities is greater (McNally, 2001). Finally, consumers can articulate their support for authentic local produce. For many purchasers, the existence of a farm shop is an important element as to why they visit that district and, consequently, it offers additionality to the local economy.

Contemporaneous with farm shop growth, speciality rural retail outlets - such as the House of Bruar (Perthshire) - have developed with Friedli and Dixon (2005) commenting on the distinct shopping experience offered by this retailer. In contrast with rural retail forms orientated towards functional primary shopping, the product mix reflects a discretionary leisure-focused shopping occasion. Consequently, the targeted segments are predominantly inshoppers seeking a blend of retail and leisure. Across the range of product categories, whether food or non-food, the common denominator is an emphasis upon countryside and rurality. Associating these elements with a particular lifestyle and aspiration is integral to these outlets appeal. This positioning is in distinct contrast with many pre-existing tourist gift retailers that are deemed to lack the desired ambience and product mix. Dedicated sections that emphasise particular brands are used in-store and whilst these brands are retailed elsewhere, the value to the outlet is enhanced since a number of product lines are marketed exclusively for that location. The increasing scale and range of some speciality outlets has 
enabled premises to cluster in one location. For example, Scotts of Stow have outlets - each focusing on a different product category - that cluster in the centre of Stow-on-the-Wold.

Developing non-store retailing, whether web-based or mail order, in tandem with store outlets has been instrumental to growth. These channels enable existing customers to continue purchasing, whilst more distant segments can be accessed. For example, the Baxters Food Group shop in Fochabers (Moray) also operates a mail order service. Ultimately, each segment complements, rather than cannibalises, one another. In common with village stores stocking local produce, similar tactics are used to emphasise the product's local origin and distinctiveness.

\section{Conclusion}

Through reviewing existing and emergent rural retail forms, the contention that the sector is in perpetual decline can be partially refuted. Existing alongside pressured trading conditions, there are sub-sectors - such as farm shops - that have grown. Evidently, there is diversity with rural retail contraction being accompanied by emergent and adapted retail forms. Across the typology, a series of contributory phenomena that characterises these more dynamic forms of rural retailing can be synthesised (Table III).

Take in Table III here

Across different rural retail forms, the growth of non-store retailing enables more distant segments to be targeted. By extending the retailer's spatial scope, the constraints of remoteness and finite population catchments have been partially negated. Growth strategies have targeted different segments simultaneously with the scope for attracting inshoppers 
accompanying non-store retailing. Increasing trade from these segments reflects the current focus of leisure-based discretionary retail spending. For these consumers, a critical factor is the ability to purchase products and consume 'experiences' that trade on an identifiable sense of rural identity. By focusing on these powerful local associations and imagery, a series of marketable assets can be harnessed. Capitalising on the distinctiveness of rural retailing allows for favourable comparisons to be made relative to more homogenised and bland retail forms. In targeting non-store together with inshopping segments, there have been growth opportunities revolving around 'localness'. Rural retailers can differentiate themselves through the positive perceptions conveyed by the imagery on the product packaging.

Existing rural retailing forms, such as market towns, have also traded on these identifiable attributes of rural identity and 'localness'. Where they have differentiating features and qualities, there have been opportunities for growth. Due to their longstanding role in servicing local residents and the wider hinterland, the community's interest and involvement can be instrumental to future development. Consequently, community engagement - within market towns and village shops - can be a mechanism for differentiation and adaptation. Village shop survival, in some instances, is dependent on the community becoming directly involved in its functioning. Achieving successful diversification, through offering greater consumer utility, is also pivotal. Essentially, community goodwill is contingent on the retail offering's adaptation and diversification being relevant.

Whilst 'virtuous' rural retailing is characterised by a variety of phenomena, a consistent theme is that the parameters, scope and ambitions have been broadened. Opportunities stemming from the expansion of discretionary retailing have allowed rural retail locations to simultaneously grow and adapt. Harnessing the marketable qualities of rural areas has been 
an intrinsic element. Although these trends display different forms and characteristics across the range of locations, they are indicative of dynamism amongst rural retailers. Existing rural retailing definitions, which have tended to be encapsulated and framed negatively, have failed to capture innovation. Formulating a sufficiently inclusive definition, which accurately encapsulates recent trends, is problematic due to the sector's diversity. These limitations are also apparent when reviewing functional shopping needs. Recent multiple store growth in market towns is not acknowledged and incorporated into existing definitions. As with discretionary shopping locations, there are distinctive attributes that market towns and village shops can base themselves upon. In instances where multiples have broadened the parameters and scale of rural retailing, there is a heightened need for existing retailers to inventively increase their utility for customers and exploit their marketable assets together with community goodwill.

\section{References}

Aberdeenshire Council. (2004), Rural Facilities Monitor 2004, Aberdeenshire Council Planning and Environmental Services, Aberdeen.

Action for Market Towns. (2002), Market towns and local foods, Action for Market Towns, Bury St Edmunds.

Action for Market Towns. (2003), Market towns and retail issues - discussion paper, Action for Market Towns, Bury St Edmunds.

Anderson, A.R. and McAuley, A. (1999), 'Marketing landscapes: the social context', Qualitative Market Research: An International Journal, Vol. 2, No. 3, pp. 176-188.

Bates, P. (1976), The Independent Grocery Retailer: Channel problems - A Report of a Survey, Research Report 23, Manchester Business School: Retail Outlets Research Unit, Manchester.

Bessiere, J. (1998), 'Local development and heritage: traditional food and cuisine as tourist attractions in rural areas’, Sociologia Ruralis, 38 (1), pp. 21-34.

BITC. (2003), Positive impact in rural communities, Business in the Community, London. 
Broadbridge, A. and Calderwood, E. (2002), 'Rural Grocery Shoppers: do their attitudes reflect their actions?', International Journal of Retail \& Distribution Management, Vol. 30, No. 8, pp. 394-406.

Burnett, K.A. and Danson, M. (2004), 'Adding or subtracting value? Constructions of rurality and Scottish quality food promotion', International Journal of Entrepreneurial Behaviour \& Research, Vol. 10, No. 6, pp. 384-403.

Byrom, J., Medway, D. and Warnaby, G. (2001a), 'Strategic Alternatives for Small Retail Businesses in Rural Areas: Evidence from the Southern Western Isles of Scotland', Manchester Metropolitan University Working Paper Series WP01/05, Manchester.

Byrom, J., Medway, D. and Warnaby, G. (2001b), 'Issues of provision and 'remoteness' in rural food retailing: a case study of the South Western Isles of Scotland', British Food Journal, 103 (6), pp. 400-413.

Byrom. J., Medway, D. and Warnaby, G. (2003), 'Strategic Alternatives for Small Retail Businesses in Rural Areas’, Management Research News, Vol. 26, No. 7, pp. 33-49.

Campaign to Protect Rural England. (2002a), Food Webs, CPRE, London.

Campaign to Protect Rural England. (2002b), Local Action for Local Foods, CPRE, London.

Campaign to Protect Rural England. (2004a), Local Foods - Policy Position Statement, CPRE, London.

Campaign to Protect Rural England. (2004b), Market Towns: Losing their Character?, CPRE, London.

Countryside Agency. (2001a), Research Notes CRN 37 Farmers markets in the south-east of England: their economic, environmental and social performance, Countryside Agency, London.

Countryside Agency. (2001b), Rural Services in 2000, Countryside Agency, London.

Countryside Agency. (2001c), The pub is the hub, Countryside Agency, London.

Countryside Agency. (2002), Trends in rural services and social housing 2001-2002, Countryside Agency, London.

Countryside Agency. (2003a), Broadband in rural areas, Countryside Agency, London.

Countryside Agency. (2003b), Trends in rural services and social housing 2002-2003, Countryside Agency, London.

Countryside Agency. (2004a), Beacon Towns: Signalling a bright future for market towns, Countryside Agency, London.

Countryside Agency. (2004b), Economies of Rural England: Reflecting the realities, Countryside Agency, London. 
Countryside Agency. (2004c), Local Products and Village Shops, Countryside Agency, London.

Countryside Agency. (2004d), Research Notes CRN 86 The new definition of urban and rural areas of England and Wales, Countryside Agency, London.

Countryside Agency. (2005), Trends in rural services and social housing 2003-2004, Countryside Agency, London.

Dawson, J.A. (1983), 'Small firms in retailing: terminal illness or just a cold?', IRS Working Paper 8303, Institute for Retail Studies: University of Stirling, Stirling.

Dawson, J.A. (2000), Future Patterns of Retailing in Scotland, Scottish Executive Central Research Unit, Edinburgh.

Dawson, J.A. and Kirby, D.A. (1979), Small Scale Retailing in the United Kingdom, Saxon House, Farnborough.

DEFRA. (2004a), DEFRA Rural Affairs Factsheets: Shops, Pubs and Post Offices, Department for Environment, Food \& Rural Affairs, London.

DEFRA. (2004b), DEFRA Rural White Paper: Market towns and a thriving local economy, Department for Environment, Food \& Rural Affairs, London.

DEFRA. (2005a), DEFRA Rural Affairs Factsheets: Access to Rural Services, Department for Environment, Food \& Rural Affairs, London.

DEFRA. (2005b), The Future of Services in Rural England - a Scenario for 2015, Department of Environment, Food \& Rural Affairs, London.

DETE. (2005), Groceries Order, Department of Enterprise, Trade and Employment, Dublin.

DETR. (2000), Our Countryside: the future, Department of the Environment, Transport and the Regions, London.

FARMA. (2004), FARMA Consumer Survey June 2004, FARMA - National Farmers Retail \& Markets Association, Southampton.

FARMA. (2005), 'Save the Planet' Buy local foods from Farmers Markets, Farm Shops \& $P Y O$, FARMA - National Farmers Retail \& Markets Association, Southampton.

Friedli, D. and Dixon, G. (2005), 'Tis the season to be wary', Scotland on Sunday Business Section, 27 November 2005, p. 5, Edinburgh.

Grampian Regional Council. (1989), Rural Shops Survey, Grampian Regional Council, Aberdeen.

Harman, R.G. (1978), 'Retailing in Rural Areas: A Case Study in Norfolk', Geoforum, Vol. 9, pp. 107-126. 
Hildebrandt, L. (1987), 'Consumer Retail Satisfaction in Rural Areas: A Reanalysis of Survey Data’, Journal of Economic Psychology, 8, pp. 19-42.

Hill, B. (2003), Rural Data and Rural Statistics, ESRC - Economic and Social Research Council, Swindon.

Hitwise. (2004), 'Rural web users most likely to visit shopping sites', www.hitwise.co.uk, December 7 2004, Hitwise Real-time competitive intelligence.

Hodge, I. and Monk, S. (2004), 'The economic diversity of rural England: stylised fallacies and uncertain evidence', Journal of Rural Studies, Vol. 20, Issue 3, pp. 263-272.

Home, N. (1993), 'Environmental Selection and Retail Change', Scandanavian Journal of Management, Vol. 9, No. 4, pp. 283-298.

Home, H. (2002), 'Rural consumers patronage behaviour in Finland', International Review of Retail, Distribution and Consumer Research, Vol. 12, No. 2, pp. 149-164.

IGD. (2005), The Local and Regional Food Opportunity, Institute of Grocery Distribution, Watford.

Jones, B. and Oliphant, R. (1976), Local Shops: Problems and Prospects, Unit for Retail Planning Information, Reading.

Jones, K. and Smith, P. (2000), 'The Rural Service Deficit', in Harrop, A. (Ed), Changing Views of Rural Britain: Why Services Matter, New Policy Institute, London, pp. 19-31.

Jussila, H., Lotvonen, E. and Tykkylainen, M. (1992), 'Business Strategies of Rural Shops in a Peripheral Region’, Journal of Rural Studies, Vol. 8, No. 2, pp. 185-192.

Kirby, D.A. (1982a), 'Aid to Small-Scale Retailing: The Norwegian Case’, European Journal of Marketing, Vol. 15, No. 1, pp. 33-47.

Kirby, D.A. (1982b), 'The case for the village shop', Retail \& Distribution Management, Vol. 10, No. 5, pp. 28-30.

LaForge, R. Reese, R. and Stanton, W. (1984), 'Identifying and attracting consumer outshoppers', Journal of Small Business Management, January, pp. 22-29.

LaTrobe, H. (2001), 'Farmers markets: consuming local rural produce’, International Journal of Consumer Studies, 25 (3), pp. 181-192.

Local Government Association. (2000), Open all Hours, LGA, London.

Lumpkin, J.R., Hawes, J.M. \& Darden, W.R. (1986), 'Shopping Patterns of the Rural Consumer: Exploring the Relationship between Shopping Orientations and Outshopping', Journal of Business Research, 14, pp. 63-81.

McNally, S. (2001), 'Farm diversification in England and Wales - what we can learn from the farm business survey?', Journal of Rural Studies, Vol. 17, Issue 2, pp. 247-257. 
Mackay, G.A. and Laing, G. (1982), Consumer Problems in Rural Areas, Scottish Consumer Council, Edinburgh.

MacNee, K. (1996), Living in Rural Scotland, Scottish Office, Edinburgh.

Marjanen, H. (2000), 'Retailing in rural Finland and the challenge of nearby cities', International Journal of Retail \& Distribution Management, Vol. 28, No. 4/5, pp. 194-206.

Meteyard, M. (2005), ‘Community shops not new’, www.newsector.co.uk, New Sector.

Miller, N.J. (2001), 'Contributions of social capital theory in predicting rural community inshopping behaviour', Journal of Socio-Economics, 30, pp. 475-493.

Miller, N.J., Besser, T.L., Gaskill, L.R. and Sapp, S.G. (2003), 'Community and managerial predictors of performance in small rural US retail and service firms', Journal of Retailing and Consumer Services, 10, pp. 215-230.

Morris, C. and Buller, H. (2003), 'The local food sector', British Food Journal, 105 (8), pp. 559-566.

NEF. (2002), Ghost Town Britain, New Economics Foundation, London.

NEF. (2003), Ghost Town Britain II, New Economics Foundation, London.

NEF. (2005), Clone Town Britain, New Economics Foundation, London.

NFU. (2002), Farmers Markets: a business survey, NFU Public Affairs, National Farmers Union.

North Devon Journal. (2003), 'Village shop in link-up with giant supermarket', North Devon Journal, Barnstaple, p. 9.

Phillips, M. and Swaffin-Smith, C. (2004), 'Market towns - victims of market forces?', International Journal of Retail \& Distribution Management, Vol. 32, No. 11, pp. 557-568.

PIU. (1999), Rural Economies, Cabinet Office Performance and Innovation Unit, The Stationery Office, London.

Powe, N.A. and Shaw, T. (2004), 'Exploring the current and future role of market towns in servicing their hinterlands: a case study of Alnwick in the North East of England', Journal of Rural Studies, Vol. 20, Issue 4, pp. 405-418.

PR Newswire Europe. (2003), 'Village stores celebrate fifth anniversary and GBP 1.5 million extra sale’, PR Newswire Europe, PR Newswire Europe, London.

Pratten, J. and Lovatt, C. (2002), 'Can the rural pub survive? - a challenge for management or a lost cause’, Management Research News, Vol. 25, No. 1, pp. 60-71.

Riecken, G. and Yavas, U. (1988), 'A taxonomy of outbuyers: A new perspective', International Journal of Retailing, 3 (1), pp. 5-15. 
Rural Development Commission. (1993), Village shops: a report on community action, RDC, London.

Rural Development Commission. (1994), Village shops mean business, RDC, London.

Rural Shops Alliance. (2005), Legislation - Regulation: The Red Tape Burden on Rural Retailers, Rural Shops Alliance, Dorchester.

Scottish Executive. (2000), The Quality of Services in Rural Scotland, Scottish Executive Central Research Unit, Edinburgh.

Scottish Executive. (2002), Scottish Household Survey: 6 Fold Urban Rural Classification, Scottish Executive Geographic Information Service, Edinburgh.

Scottish Office. (1995), Rural Scotland: People, Prosperity \& Partnership, HMSO, Edinburgh.

Shaw, G. (1982), 'Structure Plan Policies for retail provision in rural areas: a case study of south-west England', Service Industries Review, Vol. 2, No. 1, pp. 38-50.

Shucksmith, M. (1990), The Definition of Rural Areas and Rural Deprivation, Scottish Homes, Edinburgh.

Simms, A. (2003), 'The rise of the British ghost town', New Statesmen, 15-30 December, pp. 35-36.

Smith, A. and Sparks, L. (1997), Retailing and Small Shops, Scottish Office, Edinburgh.

Smith, A. and Sparks, L. (2000), 'The role and function of the independent small shop: the situation in Scotland', International Review of Retail, Distribution and Consumer Research, Vol. 10, No. 2, pp. 205-226.

Smith, A. and Sparks, L. (2001), 'The Independent Small Shop in Scotland: a Discussion of Roles and Problems’, Scottish Geographical Journal, 116 (1), pp. 41-58.

Sullivan, P. and Savitt, R. (1997), 'Store patronage and lifestyle factors: implications for rural grocery retailers', International Journal of Retail \& Distribution Management, Vol. 25, No. 11, pp. 351-364.

The Grocer. (1996), ‘A five point plan for village shop survival’, The Grocer, London.

Thompson, J.R. (1971), 'Characteristics and behaviour of outshopping consumers', Journal of Retailing, 47 (Spring), pp. 70-80.

Vias, A.C. (2004), 'Bigger stores, more stores, or no stores: paths of retail restructuring in rural America’, Journal of Rural Studies, Vol. 20, Issue 3, pp. 303-318.

Weatherell, C., Tregear, A. and Allinson, J. (2003), 'In search of the concerned consumer: UK public perceptions of food, farming and buying local', Journal of Rural Studies, Vol. 19, Issue 2, pp. 233-244. 
White, S.D., Guy, C.M. and Higgs, G. (1997), 'Changes in Service Provision in Rural Areas. Part 2: Changes in Post Office Provision in Mid Wales: A GIS-based Evaluation', Journal of Rural Studies, Vol. 13, No. 4, pp. 451-465.

Williams, C.C. (2003), 'Harnessing Social Capital: Some Lessons From Rural England', Local Government Studies, Vol. 29, No. 1, pp. 75-90.

Youngs, J. (2003), 'Consumer direct initiatives in North West England farmers markets', British Food Journal, Vol. 105, No. 8, pp. 498-530. 
Table I. Dynamism and innovation in market town retailing

\begin{tabular}{|c|c|}
\hline Town and types of assets/activities & ications \\
\hline $\begin{array}{l}\text { Brigg - North Lincolnshire (population } \\
\mathbf{5 7 6 8 )} \\
\text { Natural and historic features; attractiveness } \\
\text { and amenity of centre } \\
\text { Annual events and fairs (horse fair) } \\
\text { Specialised periodic markets } \\
\text { Periodic sporting and leisure events (cycling } \\
\text { festival) }\end{array}$ & $\begin{array}{l}\text { Scope for growth in visitor numbers } \\
\text { Scope for differentiation that capitalises on } \\
\text { distinctive heritage }\end{array}$ \\
\hline $\begin{array}{l}\text { Barnard Castle - Durham (population } \\
\text { 5700); Middleton-in-Teesdale (population } \\
\text { 1600) } \\
\text { 'Teesdale Marketing' strategy elements: } \\
\text { Shop refurbishment } \\
\text { Christmas festival } \\
\text { Farmers markets } \\
\text { Promotional campaign targeting regional, } \\
\text { national and international travel trade }\end{array}$ & $\begin{array}{l}\text { Scope for differentiating town by enhancing } \\
\text { infrastructure } \\
\text { Scope for visitor growth through seasonal } \\
\text { focus } \\
\text { Scope for growth in resident and non-resident } \\
\text { segments } \\
\text { Scope for increasing regional day visitors } \\
\text { together with short-break segment }\end{array}$ \\
\hline $\begin{array}{l}\text { Bridgport - Dorset (population 7500) } \\
\text { Active fishing port and visible/vibrant arts } \\
\text { scene. } \\
\text { Prosperous local food sector together with } \\
\text { food markets/Food Week. } \\
\text { Year of local food (2004) }\end{array}$ & $\begin{array}{l}\text { Scope for visitor growth on account of } \\
\text { amenity and attractiveness } \\
\text { Scope for differentiation by capitalising on } \\
\text { local food heritage: engendering resident } \\
\text { pride/shopping benefit } \\
\text { Scope for differentiating rural area to non- } \\
\text { resident segments by focusing on distinctive } \\
\text { assets }\end{array}$ \\
\hline $\begin{array}{l}\text { Richmond - North Yorks (population } \\
\text { 8970) } \\
\text { Attractiveness of natural setting and } \\
\text { townscape } \\
\text { Marketing campaign centred on image } \\
\text { building, leaflets, retail training and } \\
\text { recognition through awards } \\
\text { New retailers stocking local produce }\end{array}$ & $\begin{array}{l}\text { Scope for differentiation due to appeal for } \\
\text { niche retailers } \\
\text { Scope for growth in residents spend through } \\
\text { fostering pride; scope for visitor growth by } \\
\text { repositioning town on charm/authenticity } \\
\text { Scope for diversification by local producers } \\
\text { and potential for visitor growth }\end{array}$ \\
\hline
\end{tabular}

Source: adapted from Countryside Agency. (2004a). 
Table II. Village shop dynamism and innovation

\begin{tabular}{|c|c|}
\hline Village and type of de & 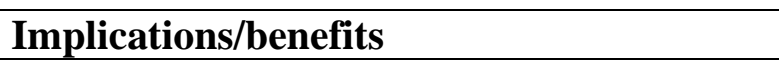 \\
\hline $\begin{array}{l}\text { Rackenford - Devon } \\
\text { Residents constituted 'Village Shop } \\
\text { Company' to stave off threatened closure of } \\
\text { old shop }\end{array}$ & $\begin{array}{l}\text { hity involvement - original } \\
\text { now 350; most households } \\
\text { lly and/or in time }\end{array}$ \\
\hline $\begin{array}{l}\text { Cartmel - Cumbria } \\
\text { Village store introduced mail-order service } \\
\text { Locally produced items constitute } 50 \% \text { of } \\
\text { stock - product packaging reflects local } \\
\text { landscape images } \\
\text { Local information, such as on transport links, } \\
\text { provided for community }\end{array}$ & $\begin{array}{l}\text { Scope for growth and diversification to non- } \\
\text { resident segments } \\
\text { Scope for differentiation/unique selling point } \\
\text { on basis of local imagery } \\
\text { Scope for adapted/extra ancillary services to } \\
\text { offer convenience to community }\end{array}$ \\
\hline $\begin{array}{l}\text { Maiden Bradley - Wiltshire } \\
\text { Village store run by community association } \\
\text { since } 2001 \\
\text { Local produce comprises } 15 \% \text { of food } \\
\text { products stocked } \\
\text { Store offers delivery services to elderly } \\
\text { customers and social space for community }\end{array}$ & $\begin{array}{l}\text { Community stake demonstrated by staffing } \\
\text { policy of using local volunteers } \\
\text { Scope for differentiation on basis of seasonal } \\
\text { promotions that target residents and visitors } \\
\text { Scope for growth in trade allied with ability } \\
\text { for store to differentiate itself on basis of } \\
\text { personalised service }\end{array}$ \\
\hline $\begin{array}{l}\text { Harberton - Devon } \\
\text { Proportion of local produce increased in line } \\
\text { with demand } \\
\text { Promotional effort targets catchment beyond } \\
\text { confines of immediate village } \\
\text { Ancillary services introduced: dry-cleaning, } \\
\text { photocopying, cash machine, delivery and } \\
\text { info board } \\
\text { Local suppliers offer facility of purchasing in } \\
\text { small quantities }\end{array}$ & $\begin{array}{l}\text { Scope for adapted product composition to be } \\
\text { positioned in accordance with segment } \\
\text { preferences } \\
\text { Scope for growth in trade } \\
\text { Scope for diversification by offering greater } \\
\text { utility to customers } \\
\text { Scope for adapted product mix to offer } \\
\text { greater variety/choice due to supply chain } \\
\text { flexibility }\end{array}$ \\
\hline
\end{tabular}

Source: adapted from NEF. (2003) and Countryside Agency. (2004c). 
Table III. 'Virtuous' rural retailing

\begin{tabular}{|c|c|}
\hline Phenomena & Example/implications \\
\hline Non-store retailing & $\begin{array}{l}\text { Rural products routed through internet, thus extending } \\
\text { spatial scope and enabling continued patronage } \\
\text { Speciality retailers access both national \& international } \\
\text { markets }\end{array}$ \\
\hline Inshopping to rural areas & $\begin{array}{l}\text { Accessibility to large population concentrations creates } \\
\text { opportunities for proximate rural regions }\end{array}$ \\
\hline $\begin{array}{l}\text { Focus upon leisure-based segments } \\
\text { orientated towards discretionary } \\
\text { spending }\end{array}$ & $\begin{array}{l}\text { Specialism towards product categories clustered in one } \\
\text { location, eg: book towns } \\
\text { Segments seeking products and 'experiences' that } \\
\text { warrant price premium and trade on rural identity }\end{array}$ \\
\hline Strong rural identity & $\begin{array}{l}\text { Distinctiveness of rural retailers creates favourable } \\
\text { comparisons with more homogeneous and identikit } \\
\text { forms of retail } \\
\text { Rural retailing may be historically embedded and trade } \\
\text { on nostalgia } \\
\text { Powerful local associations and identifiable character } \\
\text { can be used as marketable assets }\end{array}$ \\
\hline $\begin{array}{l}\text { Increased consumer interest in } \\
\text { 'localness' }\end{array}$ & $\begin{array}{l}\text { Locally derived food produce targeted to consumers } \\
\text { with mobility and discretionary spend } \\
\text { Food packaging generates positive local associations }\end{array}$ \\
\hline Strong community role & $\begin{array}{l}\text { Rural retailers act as a local information conduit } \\
\text { Rural retailers central to the fabric of social life } \\
\text { Longstanding role of market towns in servicing their } \\
\text { hinterland } \\
\text { Community events associated with village shop } \\
\text { Village shop associations enable community to have a } \\
\text { greater stake }\end{array}$ \\
\hline $\begin{array}{l}\text { Accessing new revenue } \\
\text { streams/diversification }\end{array}$ & $\begin{array}{l}\text { Attraction of rural areas to non-residents: day visitors } \\
\text { and tourists } \\
\text { Consumer utility increased by amalgamating functions } \\
\text { to create mixed-merchandising in village shops } \\
\text { Technology improvements in village shops alleviates } \\
\text { geographic isolation of consumers } \\
\text { Introduction of supermarket brands in collaborative } \\
\text { ventures between village shops and national chains }\end{array}$ \\
\hline
\end{tabular}

Source: authors research 


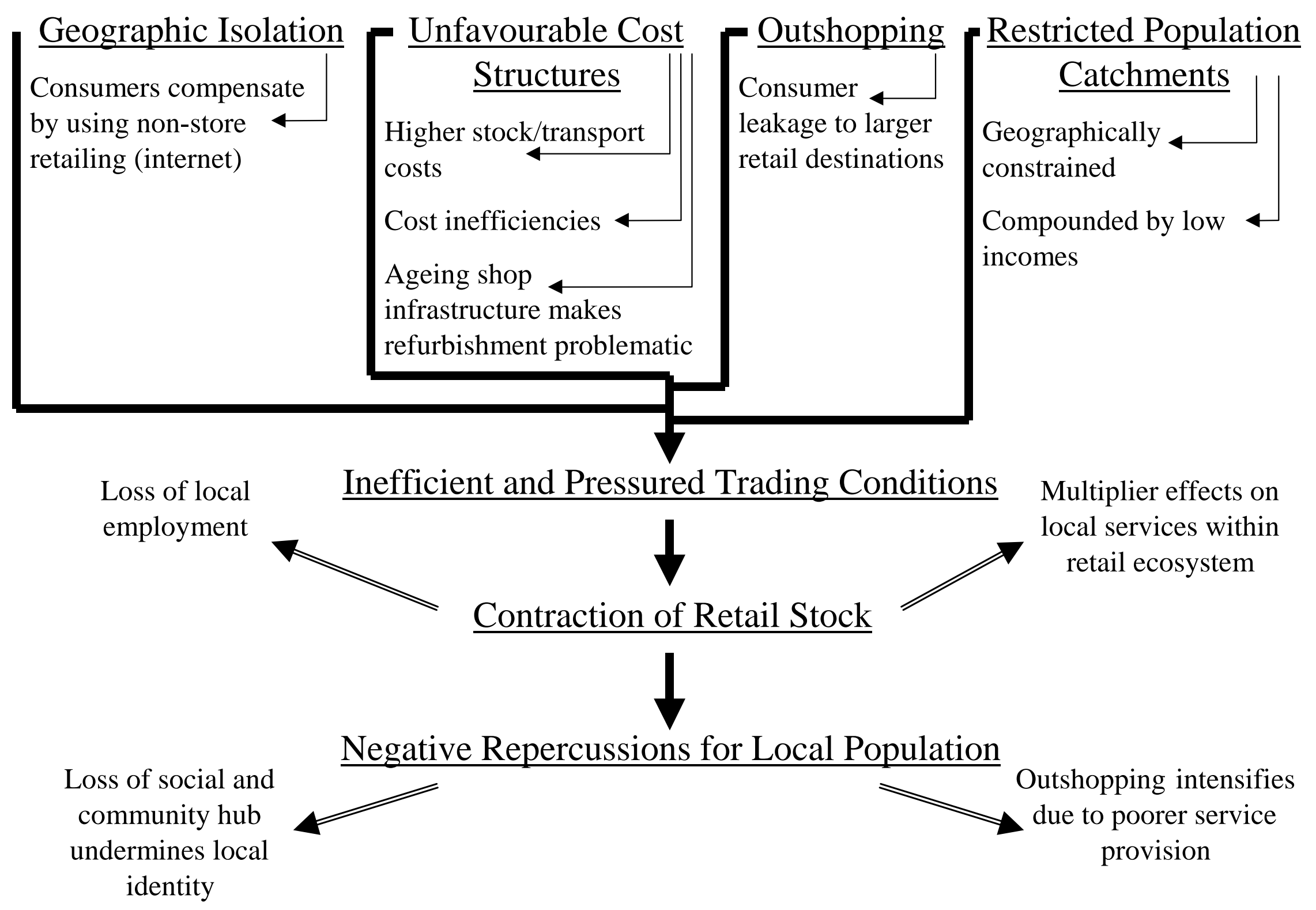

